\section{Activation of Amino-Acids in Relation to the Synthesis of Silk Proteins}

THE 'activation' of the carboxyl groups in aminoacids is often assumed to be an indispensable preliminary stage in the biosynthesis of protein. The rate of the activation is known to vary with various amino-acids. The question arises whether there is any relation between the rate of activation of an amino-acid and its content in the protein. The silkglands of the silkworm lend themselves particularly well to the study of such a problem since they produce two well-defined proteins, the amino-acid composition of which is known. While the posterior silk-gland produces 'fibroin', which contains 42 per cent of glycine and 28 per cent of alanine, the middle silkgland produces 'sericin' containing 30 per cent of serine ${ }^{1}$. We have studied the activation of a number of amino-acids present in these two proteins of the silkworm caterpillars (Bombyx mori L.). The ' $p \mathrm{H} 5$ enzymes' were obtained from the posterior and middle silk-glands as well as from the hæmolymph. The hydroxamic method was used to determine the rate of the activation of the carboxyl groups in the aminoacids. The composition of the enzymatic mixture was approximately the same as that referred to by Davie, Koningsberger and Lipmann ${ }^{2}$. The results which we obtained are given in Table 1.

Table 1. The Rate of THE AMino-ACID ACTIVATION IN SILK-Glands AND IN THE HAMOLYMPH OF SILKWORM CATERPILLARS. THE RESULT MEAN

\begin{tabular}{|c|c|c|c|}
\hline \multirow[b]{2}{*}{ Amino-acids } & \multicolumn{3}{|c|}{$\mu$ mole of hydroxamates $/ 1 \mathrm{mgm}$. of protein $/ \mathrm{hr}$. } \\
\hline & $\begin{array}{l}\text { Posterior } \\
\text { silk gland }\end{array}$ & $\begin{array}{c}\text { Middle } \\
\text { silk gland }\end{array}$ & Hæmolymp̣h \\
\hline Alanine & $0.068 \pm 0.03$ & $0.088 \pm 0.03$ & $0.085+0.04$ \\
\hline Glycine & $0.038 \pm 0.00$ & $0.073 \pm 0.01$ & $0.057 \pm 0.02$ \\
\hline Glutamic acid & $0.031 \pm 0.02$ & $0.258 \pm 0.07$ & $0.105 \pm 0.03$ \\
\hline Histidine & $0.098 \pm 0.01$ & $0.286 \pm 0.15$ & $0.060 \pm 0.02$ \\
\hline Serir & $0.318 \pm 0.05$ & $0.168 \pm 0.04$ & $0.079 \pm 0.02$ \\
\hline Tryptophan & $0.623 \pm 0.10$ & $0.406 \pm 0.21$ & $0.071 \pm 0.03$ \\
\hline Tyrosine & $0 \cdot 600 \pm 0 \cdot 19$ & $0.370 \pm 0.18$ & $0.150 \pm 0.06$ \\
\hline
\end{tabular}

The two amino-acids which showed the highest rate of activation were tryptophan and tyrosine. Yet it is known that there are only traces of tryptophan in the proteins of the silk. Glycine, on the other hand, showed the lowest rate of activation in spite of its high concentration in the silk proteins. Thus no relationship could be established between the rate of the activation of amino-acids as measured by the hydroxamic method and their actual concentration in the proteins. We then decided to investigate the possibility that the activation of glycine proceeds mainly through transacylation. In view of the high rate of activation of tryptophan and tyrosine it seemed that the active forms of these two aminoacids might participate in such a process. An attempt was therefore made to observe activation of glycine in the presence of either tryptophan or tyrosine. Chromatographic analysis of the mixtures, however, did not reveal the presence of any hydroxamic acids other than those of tryptophan or tyrosine. As regards the possibility that glycine activation occurs outside the silk-glands, we found that in the hæmolymph the activation is negligible. Thus the question as to how glycine is introduced in the course of silk protein synthesis still remains open. Our results, however, suggest that the incorporation of amino-acids into protein must occur by means other than the activation of the carboxyl groups.
A detailed report of this work will be published in the Acta Biochimica Polonica.

\section{J. HeLler \\ P. SZAFRAKSKI \\ E. Surkowskr}

Institute of Biochemistry and Biophysics, Polish Academy of Sciences,

Warsaw. Nov. 24.

${ }^{2}$ Fukuda, T., Kirimura, J., Matuda, M., and Spzuki, T., J. Biochem., 42, 341. (1955).

${ }^{2}$ Davie, E. W., Koningsberger, V. V., and Lipmann, F., Arch. Biochem. Biophys., 65, 21 (1956).

\section{Casease in Entamoeba histolytica}

Casease, the proteolytic, casein-hydrolysing enzyme, has been reported in many bacteria. It has not hitherto been detected in the protozoan, Entamoeba histolytica. In earlier studies, Nakamura ${ }^{1}$ reported the absence of casease in certain strains of the amœbre. It was thought that the failure to demonstrate the enzyme might have been due to the comparatively large amounts of casein in the assay plates. Therefore, the experiments were repeated using a modification of the same method but incorporating smaller concentrations of casein in the test plates.

The amœbæ were cultured in coagulated whole egg slants overlaid with Ringer-liver extract solutions. Cultures $72 \mathrm{hr}$. old were pooled and washed four times in saline solution. The supernatant from the final washing was also tested for enzymatic activity; any remaining associated bacteria from the amœba stock cultures would be contained in this supernatant. In addition, the associated bacteria were assayed for casease activity in the absence of the amœbæ.

The method consisted of placing large drops of material to be assayed on the surface of 1.0 per cent agar plates containing 0.2 per cent casein, incubating for $12 \mathrm{hr}$. at $20-25^{\circ} \mathrm{C}$., and flooding the agar plates with a mercuric chloride-hydrochloric acid solution (a protein-precipitating agent). Clear areas in the opaque casein-agar plates indicated zones of casein hydrolysis.

Two strains of $E$. histolytica (large race HUS-105 and small race Washington) hydrolysed casein. However, the supernatant from the fourth washing and the cultures of the associated bacteria did not hydrolyse casein. The amcbic casease was destroyed by heating at $65^{\circ} \mathrm{C}$. for $5 \mathrm{~min}$. but not by a temperature of $55^{\circ} \mathrm{C}$. for $5 \mathrm{~min}$. The enzyme activity at varying $p \mathrm{H}$ values was studied, and it was found to be active between $p H \mathbf{5}$ and $p \mathrm{H} 8$. Thus, another proteolytic enzyme is established in $E$. histolytica. These experiments on the proteolytic activity of the amcbæi ${ }^{2-4}$ may eventually yield clues on the mechanisms of pathogenicity of this important parasite.

This work was supported (in part) by the Office of Surgeon General, Department of the Army, Contract No. $D A-49-007-M D-711$.

Mitsuru Nakamura

PhILIP R. EDWARds, JUN.

Department of Bacteriology,

Montana State University, Missoula, Montana. Nov. 25

${ }^{1}$ Nakamura, M., J. Protozool., 4, Supp., 18 (1947).

${ }^{2}$ Neal, R. A., Nature, 178, 599 (1956).

${ }^{3}$ Harinasuta, C., and Maegraith, B. G., Trans. Roy. Soc. Trop. Med. Hyg., 48, $285(1954)$

- Meleney, H. Є., Amer. J. Trop. Med. Hyg., 6, 487 (1957). 